DOI: 10.20472/IAC.2018.935.008

\title{
MEHMET BASAR
}

Anadolu University, Turkey

\section{OBSTACLES FOR ACADEMIC ENTREPRENEURSHIP IN TURKEY}

\begin{abstract}
:
Today, as a result of the knowledge economy, universities are focusing more on creating commercial knowledge along with their primary tasks - education and research. Increasing demand for university-industry collaboration, universities' new roles in the economic development through technology transfer, and commercialization of knowledge are among the major factors that lead to concepts such as "entrepreneurial university" and "academic entrepreneur". Academic entrepreneurship is actually a wider concept that covers all the efforts and activities toward the commercialization of the scientific research outputs of the universities and their industrial partners. In Turkey, Supreme Council for Science and Technology supports academic entrepreneurship activities and encourages potential academic entrepreneurs through various support mechanisms. However, there are many problems that academic entrepreneurs encounter and this study aims to discuss possible solutions for these problems and obstacles.
\end{abstract}

\section{Keywords:}

Entrepreneurial University, Academic Entrepreneur

JEL Classification: L26, L31, 100 